\title{
REVENUE COMPARATIVE ANALYSIS OF INTENSIVE AND SEMI INTENSIVE SHEEP BREEDER ON THE VILLAGES OF CELAWAN VILLAGE, PANTAI CERMIN SUBDISTRICT, SERDANG BEDAGAI REGENCY
}

\author{
Purnama Ketaren, I Sembiring, S Umar, A H Daulay and N D Hanafi \\ Animal Production Study Program, Faculty of Agriculture, University of Sumatera Utara Medan \\ 20155 \\ E-mail: tarenku@yahoo.com
}

\begin{abstract}
This study's objective was to investigate the income and R / C of sheep business. This research was conducted on Cilawan Village,Pantai Cermin Sub District, Serdang Bedagai Regency, Sumatera Utara Province for 2 months starting from September until November 2017. The study was a survey which used Determination Method. Number of samples were $30 \%$ of total number of breeder in research area; there were 8 respondents whose intensive breeders and 30 respondents whose semi intensive breeders. The data used in this research were primary data and secondary data. Primary data were the result of interviews with respondents and secondary data were obtained from the Central Bureau of Statistics.

The results showed that intensive breeder earned income smaller compared to semi intensive breeder. Income on every sheep sale was $\mathrm{Rp} 3.468 .241$,-on intensive and $\mathrm{Rp}$ $5.794 .982,-$ on semi intensive breeder and the value of $\mathrm{R} / \mathrm{C}$ was 0.144 . The conclusion of this study that sheep breeding system in Celawan Village Regency consisted of two maintenance system, intensive and semi intensive system which gave different effect to farmer's income. This was because intensive maintenance systems required more costs for feed and labor costs compared to semi intensive system.

Keywords: income, sheep,intensive breeder and semi intensive breeder
\end{abstract}

\section{Introduction}

Celawan village has an area of $19.65 \mathrm{~km} 2$ consisting of 1770 families with a total of 6600 people who mostly work as farmers and breeders. Sheep population in 2014 reached 5,180 heads [1]. Usually in the morning most of the breeders whose live close to plantation area, they shepherd their sheep to the plantation area and cage the sheep at night. Unlike the breeders whose live rather far from the plantation area, they raise sheep with intensive systems because their grazing sites do not exist. The breeder provides the feed and feeds it into the cage [2]. 


\section{Materials and Methods}

The study was a survey which used Determination Method. Number of samples were $30 \%$ of total number of breeder in research area; there were 8 respondents whose intensive breeders and 30 respondents whose semi intensive breeders. The data used in this research were primary data and secondary data. Primary data is obtained directly from the respondent's monitoring of sheep business activity through interviewing technique and filling the questionnaire list, while secondary data is obtained from various related institutions such as Central Bureau of Statistics, government agencies and other private.

Parameters were cost, income, revenue between intensive and semi-intensive breeders. A comparative test used t test (t-test in order to know the feasibility of sheep business) then conducted further test by using SPSS 22.0 application. Further tests were conducted to see whether or not the revenue difference of the two maintenance systems was significant [3].

\section{Results and Discussion}

\subsection{Fixed Costs and Variable Costs}

Semi intensive maintenance system had higher fixed cost compared to intensive system maintenance, that was $\mathrm{Rp} 2,968,333$ with composition $23,73 \%$ from total cost spent for sheep breeding business. The intensive system has an average cost of Rp 1,327,438,- with a composition of $17.82 \%$ of the total cost of $\mathrm{Rp} 6,720,250,-$. The composition of expenditures for variable costs on intensive systems was greater, I e $71.53 \%$ whereas in semi intensive maintenance system only $61.29 \%$. Although the composition of expenditures for variable costs on intensive systems was higher, the total cost for variable costs was still lower, i.e $\mathrm{Rp} 5,329,813,-$ compared to expenditures for variable costs in the semi-intensive maintenance system, which was Rp 7,665,09,-

Table 1. Average fixed and non-permanent costs of respective livestock farmers

\begin{tabular}{lcccc}
\hline \multirow{2}{*}{ Types } & \multicolumn{4}{c}{ Maintenance System } \\
\cline { 2 - 5 } & Intensive $(\mathrm{Rp},-)$ & $\%$ & Semi Intensive $(\mathrm{Rp},-)$ & $\%$ \\
\hline Cost of seeds & 793.750 & 10,65 & 1.873 .333 & 14,98 \\
Fixed cost & 1.327 .438 & 17,82 & 2.968 .333 & 23,73 \\
Variable costs & 5.329 .813 & 71,53 & 7.665 .092 & 61,29 \\
\hline Total cost & 6.720 .250 & 100 & 10.633 .625 & 100 \\
\hline
\end{tabular}

\subsection{Income}

The amount of income on the intensive maintenance system had an average value of $\mathrm{Rp}$ 11.0000.000,- while the semi-intensive system was $21,196,667,-$. Revenue was obtained from the sale of sheep and the final value of sheep from unsold sheep. In intensive and semi intensive maintenance system, the final value of livestock had the highest composition of breeding total ranging from $78.98 \%$ and $73.16 \%$

Table 2. Table Average of benefit of each respondent's breeder

\begin{tabular}{lcccc}
\hline \multirow{2}{*}{ Benefit } & \multicolumn{5}{c}{ Maintenance System } \\
\cline { 2 - 5 } & Intensive $(\mathrm{Rp},-)$ & $\%$ & Semi Intensive $(\mathrm{Rp},-)$ & $\%$ \\
\hline Final value of & 8.687 .500 & 78,98 & 15.506 .666 & 73,16 \\
livestock & 2.312 .500 & 21,02 & 5.690 .000 & 26,84 \\
Sale of livestock & & & & \\
\hline
\end{tabular}




\begin{tabular}{lllll}
\hline Total acceptance & 11.000 .000 & 100 & 21.196 .667 & 100 \\
\hline
\end{tabular}

\subsection{Revenue}

In intensive system maintenance earn income per smaller breeders compared to maintenance in semi-intensive system, respectively Rp 4,279,750 and Rp 10,563,242. While the income for every sheep, sequentially Rp 3.468.241 and Rp 5.794.982.

Tabel 3. Average indome of sheep bredeer

\begin{tabular}{|c|c|c|}
\hline \multirow{2}{*}{ Types } & \multicolumn{2}{|c|}{ Maintenance System } \\
\hline & Intensive $(\mathrm{Rp},-)$ & Semi Intensive (Rp,-) \\
\hline Revenue / breeders & $\mathrm{Rp} \quad 4.279 .750$ & Rp 10.563.242 \\
\hline Revenue / ST & $\mathrm{Rp} \quad 3.468 .241$ & Rp $\quad 5.794 .982$ \\
\hline
\end{tabular}

\subsection{Comparative Test of Farmer's Revenue and Revenue Cost Ratio $(R / C)$}

Table 4. Different average income test results per farmer, income per unit of livestock, and R / C livestock

\begin{tabular}{|c|c|c|c|c|}
\hline \multirow{2}{*}{ No. } & \multirow{2}{*}{ Uraian } & \multicolumn{2}{|c|}{ Maintenance System } & \multirow{2}{*}{ Sign } \\
\hline & & Intensive & Semi intensive & \\
\hline 1 & Revenue / breeders & $\operatorname{Rp} 4.279 .750,-$ & Rp 10.563.241,- & $0,054^{\mathrm{a}}$ \\
\hline 2 & Revenue / ST & Rp 3.468.242,-- & Rp 5.794.982,-- & $0,016^{\mathrm{ab}}$ \\
\hline 3 & $\mathrm{R} / \mathrm{C}$ & 1,65 & 1,86 & 0,144 \\
\hline
\end{tabular}

Description: $\mathrm{ab}=$ very different real

By observing data, there was a very real difference in income per rancher between intensive and semi intensive system maintenance with a significance value of $0.054(\mathrm{P}<0.05)$. The average income per farmer in the livestock business with intensive maintenance system, which is around Rp 4,279,750,- and the average income per farmer with semi-intensive maintenance system ranges from $\mathrm{Rp} 10,563,241,-$.

Based on the result of average difference test to the value of $\mathrm{R} / \mathrm{C}$ obtained result which is not significantly different between maintenance with intensive and semi intensive maintenance system. The result of $t$ test shows probability value is $0,144(\mathrm{P}>0,05)$, so there is no difference between the feasibility of the livestock business with intensive maintenance system and semi intensive system. However, based on the feasibility test the value of R / C> 0.05 , which states that both businesses are equally feasible to be implemented ]4].

\subsection{Analysis of Factors Affecting Farm Income With Intensive and Semi Intensive Maintenance Systems}

The result of regression analysis with SPSS 22.0 on factors influencing farmer's income with intensive maintenance system can be seen in Table 5 .

Table 5. Factor Analysis Affecting Farmer's Revenue with Intensive Maintenance System

\begin{tabular}{llll}
\hline Model & $\begin{array}{l}\text { Regression } \\
\text { Coefficient }\end{array}$ & $\mathrm{T}$ & Sig. \\
\hline (Constant) & 192982 & $-1,057$ & 0,401 \\
Seed Costs & 2,938 & 5,567 & $0,031^{\mathrm{ab}}$ \\
Sale of livestock & 0,754 & 9,653 & $0,011^{\mathrm{ab}}$ \\
Number & 2491468 & 2,413 & 0,137
\end{tabular}




\begin{tabular}{|c|c|c|c|}
\hline Fixed cost & $-1,008$ & $-2,158$ & 0,164 \\
\hline Variable Cost & $-0,243$ & $-1,877$ & 0,201 \\
\hline R2 & & & 0,999 \\
\hline F hit & & & 401,171 \\
\hline Sig & & & 0,002 \\
\hline
\end{tabular}

Description: $\mathrm{ab}=$ very different real

Based on Table 5, the income equation of farmers with intensive maintenance system is as follows:

$\mathrm{Y}=192982+2,938 \mathrm{X} 1+0,754 \mathrm{X} 2+2491468 \mathrm{X} 3-1,008 \mathrm{X} 4-0,243 \mathrm{X} 5$

Table 6. Factor Analysis Affecting Farmer's Income with Semi Intensive Maintenance System

\begin{tabular}{llll}
\hline Model & Regression Coefficient & T & Sig. \\
\hline (Constant) & 3315207,452 &,- 375 & 0,711 \\
Seed Costs & 1,362 &, 229 & 0,821 \\
Sale of livestock & 2,922 & 4,049 & $0,000^{\mathrm{ab}}$ \\
Number of Livestock & 106952,720 &, 483 & 0,634 \\
Fixed cost & $-3,064$ & $-0,520$ & 0,608 \\
Variable Cost & 0,327 & 0,295 & 0,770 \\
\hline R2 & & & 0,593 \\
F hit & & & 6,997 \\
Sig & & 0,000 \\
\hline
\end{tabular}

Description: $\mathrm{ab}=$ very different real

Based on Table 6, the income equation of farmers with intensive maintenance system is as follows:

$\mathrm{Y}=3315207,452+1,362 \mathrm{X} 1+2,922 \mathrm{X} 2+106952,720 \mathrm{X} 3-3,064-0,327 \mathrm{X} 5$

\subsection{Test the effect of variables simultaneously}

3.6.1. $R$ square value

In Table 6 it can be seen that the R Square value for multiple linear regression of farmers with intensive maintenance system was 0.99 , it means that all independent variables, ie seed cost, livestock sales, livestock number, fixed cost and variable cost influence farmer income with system maintenance of 99\% while in semi intensive livestock maintenance all independent variables studied only affect farmers income of 59.3\% while the rest s a variable not included in this study [5].

\subsubsection{Effect of variables simultaneously.}

The value of $\mathrm{F}$ calculated in intensive maintenance system $(401,71)$ with significance level $0,002(\mathrm{P}$ $<0,05)$, while at semi intensive maintenance system $(6,997)$ with significance level $0,000(\mathrm{P}<0,05)$, meaning that simultaneously all independent variables studied simultaneously affect the income of sheep breeders in the village of Celawan. If all the independent variables are experiencing simultaneous gain, it will cause a decrease in the breeder's gains, and vice versa [6].

\subsubsection{Constant Value}

Constant value is also called the coefficient intersept in lineaar regression, meaning that if all free variables are considered zero or production does not exist then the income value received by sheep breeders with intensive system is $\mathrm{Rp} 192.982$.- / year and income received by farmers with semi-intensive maintenance system is Rp 3.315. 207,452,- years [7]. 


\subsection{Partial Variable Effect Test}

3.7.1. Livestock Variables

Regression coefficient value for the cost of seeds on animal husbandry with intensive system amounted to 2.938 which means that any occurrence of price increase of seeds as much as Rp 1 will lead to increase in farmer's income with intensive system of Rp 2.938. However, this is different in semi-intensive system maintenance, the variable cost of seedlings does not give a real effect on the income of farmers with the value of probability value to the livestock business of 0.821 (P> 0.05). Semi-Intensive regression coefficient value of 1.362 [8].

\subsubsection{Sheep Selling PricePartially}

Sheep selling price gives significant effect to intensive and semi intensive farmer's income $(\mathrm{P}>0,05)$. The regression coefficient of livestock sales on intensive system is 0,754 and in semi intensive system 2,928

\subsubsection{Number of Livestock}

The regression coefficients for the number of livestock variables in intensive and semi-intensive systems are respectively as follows 2491468 and 106592,72 .

\subsubsection{Fixed cost}

From the results of the study note that variable cost does not give a real effect to the income of farmers with intensive and semi intensive maintenance system $(\mathrm{P}>0.05)$. The result of partial analysis shows the value of regression coefficient for variable cost is -1.008 and at variable cost in semi intensive system ranges - 3,064.

\subsubsection{Cost}

The result of partial analysis shows the value of regression coefficient for variable cost equal to - 0,243 and at variable cost at semi intensive system about 0,327 . This means that any expenditure of Rp 1000 will cause a decrease in the income of sheep breeders with intensive system of Rp 243.-, while the semiintensive system will provide additional revenue of breeders of $\mathrm{Rp} 327 .-$

\section{Conclusions}

Semi-intensive maintenance system was easier than intensive system maintenance. This was because intensive maintenance systems require more costs for the cost of feed and labor for maintenance. Breeders were advised to perform sheep breeding in semi-intensive system because based on feasibility test and comparative test show that sheep breeding with semi-intensive system was more favorable to farmers.

\section{References :}

[1] Dinas Peternakan Kabupaten Serdang Bedagai, 2016. Laporan Tahunan (Annually Report).

[2] Badan Pusat Statistik Kabupaten Serdang Bedagai, 2016. Kecamatan Pantai Cermin Dalam Angka 2016. Diakses dari: http://serdangbedagaikab.bps.go.id

[3] Winartha, I. M. 2006. Metodologi Penelitiaan Sosial Ekonomi. Andi. Yogyakarta (Socio-Economic Research Methodology).

[4] Tohir, K. A,. 1991. Seuntai Pengetahuan Usahatani Indonesia. Rineka Cipta. Jakarta. (A Knowledge of Indonesian Farming).

[5] Tomaszewska, M. W., I. M. Mastika. A. Djajanegara, S. Gardiner dan T.R. Wiradarya. 1993. Produksi Kambing dan Domba di Indonesia. Universitas Sebelas Maret, Surabaya. (Goat and Sheep Production in Indonesia). 
[6] Widjaja, K., 1999. Analisis Pengambilan Keputusan Usaha Produksi Peternakan. Lembaga Pengabdian Kepada Masyarakat. Institut Pertanian Bogor. Bogor. (Analysis of Decision Making of Livestock Production. Institute of Community Service).

[7] Sugiyono. 2003. Metode Penelitian Bisnis. Cetakan Kelima:Penerbit Bandung: CV. Alfabeta (Business Research Methods).

[8] Cahyono, B. 1998. Beternak Domba dan Kambing. Kanisius, Yogyakarta (Breeding Sheep and Goat).. 